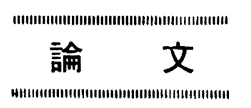

UDC $531.717 .1: 53.082 .79: 669.14-122$

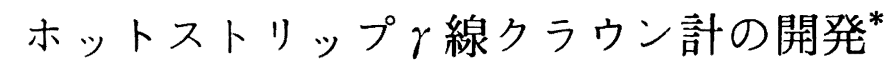

宮川一男**·市鴆勇*** · 江頭 武二****

\title{
Development of Hot-strip Crownmeter Using $\gamma$-ray
}

\author{
Kazuo Miyagawa, Isamu IchijImA, and Takeji EgAshirA
}

\section{Synopsis:}

Strip crown measurements have been requested by strip mills for the production of uniform strip. An onlirie strip crown meter has been developed using Am $\gamma$-ray. This paper deals with the problems for the development of the crown meter. Main features of this instrument are using relatively large radiation source and narrow rectangular $\gamma$-ray beam. It takes about one minute to scarm entire with of strip, and the accuracy of two microns of thickness was obtained.

(Received June 30, 1972)

\section{1. 緒}

\section{言}

ストリップの幅方向断面形状, すなわち幅方向の厚さ 分布形状は, 鋼板のクラウン形状といわれ, ホット, コ ールドストリップに関して次の二つの観点から技術的に 重要な因子である.

まず冷間圧延成品の形状，または平坦度を左右する玦 定的な要因は, ホットストリップのクラウン形状であ る. センターバックル (中のび) とか, ウェイヴィエッ シ（耳波）は明らかにホットストリップのクラウン形状 と冷間圧延時のロールクラウン形状の不整合が原因して いる. またりューダースライン（耳しわ，腰折れ）の発 生はさらに強度なクラウン形状不整合と考えられてい る.

さらに電磁鋼板のように打ち抜いてから積層して使う 場合には，積層されることにより，個々の打ち抜きピー ス内のわずかな偏差が積算され, 結果として大きな傾き を生じる. また容器材として使用される場合に, 用途に よつてはその重量管理がきびしく要求され，したがつて 素材の厚さの均一性が，きわめて高くなければならな w.

このような要請から，ストリップのクラウン形状を迅 速に, 精度よく計測する必要を生じた. ところが, 従来 行なわれていた方法は，切断サンプリングした試料を、 イクロメーターで測定する方法がとられ，人手もかかる し，測定結果が得られるまでに時間がかかつたために， 素材クラウン形状と冷延鋼板成品形状の対応関係を求め
た解析や，日常の形状管理が十分に行なわれていなかつ た.

あたかもこの要請にこたえるかのように，この時期に きわめて高精度の $\gamma$ 線厚さ計が開発された ${ }^{1)}$ ， この厚さ 計は ${ }^{241} \mathrm{Am}$ の 線を利用したものであり，応答速度が 大きくかつ高精度測定ができるものであり，本交に詳述 するように多くの長所を有している. 䇥者らはこの点に 着目し，鋼板クラウン計として非破壊測定が可能な装置 の開発を試み ${ }^{2)}$, 冷延工場, 酸洗ラインに設置実用化し た.

最近にいたり，この種 $\gamma$ 線鋼板クラウン計の利用が活 発となり ${ }^{3) \sim 5)}$ 各所で活用されている. そこでこの装置開 発についての試験過程および結果を報告し, 同時に将来 技術への応用, 改善に関しての考察を行なつた.

\section{2. 試 験 装 置}

実験に供された $\gamma$ 線厚さ計は ${ }^{241} \mathrm{Am}$ を線源とし, 電 離箱形の検出器を持ちその出力をレートメータを介して 記録させるものである. 従来の厚さ計を改良した点は, 幅方向での厚さ変化をこまかくとらえることと，エッシ 近傍までその厚さを測定する必要があることから，ビー ムを幅方向に狭く, 压延方向に長い形状にするため, 幅 を 6〜 $12 \mathrm{~mm}$, 長さ $60 \mathrm{~mm}$ のスリットを線源空にとり

\footnotetext{
* 昭和47年 6 月 30 日受付

** 新日本製鉄 (株) 君津製鉄所 工博

*** 新日本製鉄 (株) 君津製鉄所

$* * * *$ 新日本製鉄 (株) 厇畑製鉄所
} 
表 1 鋼板断面形状測定試験装置 （神戸工業(株)製）

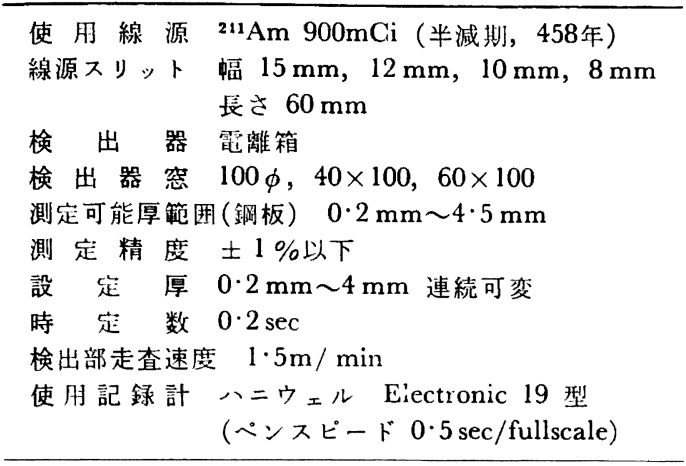

つけた.このようにすると有効な放射線量が減少するの で，線源としては通常の厚さ計の 3 倍の $900 \mathrm{mC}_{\mathrm{i}}$ を使用 した.

計器の時定数は厚さ計としては非常に短く設定し，検 出部のすばやい走查速度に応じられるようにした。

試験装置の仕様の概要は表1のとおりである.

装置設置場所としては，熱延コイルの断面形状を観察 するのが目的であるので熱延コイルが通板するラインが
考えられたが，連熱ラインは高温でしかも高速であるの で，この場所をさけて酸洗ライン入測に設置することに した：測定条件を決定するために，まず最初実験室で採 取鋼板試料について測定した.さらに酸洗工場では第 1 号酸洗ラインのアップカットシャーとウェルダーとの間 に設置して，オンライン試験を実施した。

\section{3. 試 験 結 果}

\section{1 予備試験結果}

オンライン試駗に先だち，試験装置を実験室に設 置 し，鋼板試料を静置してこの装置の再現性および精度， 他の測定方法との比較, 測定結果記録と鋼板の位置対応 のつけ方，とくにエッジから一定位置の 測定方法の検 討, 異常微小溜起すなわち, ビルトアップの検出能力な どについて種々検討した.

\section{$3 \cdot 1 \cdot 1$ 再現精度試験}

ホットコイルより採取した鋼板について本装置を幅方 向に走査して測定した結果を Fig. 1(1)，（2）に示す. それぞれ幅方向に往復走査させた結果であるが，いずれ も往きの結果と復りの結果とは, $2 \mu$ 程度の差に収まり よく合致しており，しかも鋼板によつて種々な断面形状
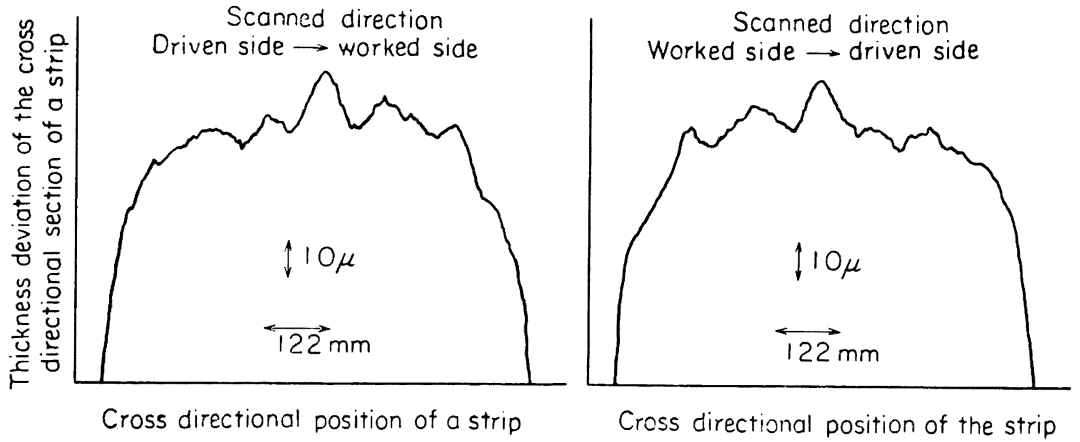

Fig. 1(1). One example of recorded profiles which shows repeatability of the test instrument.

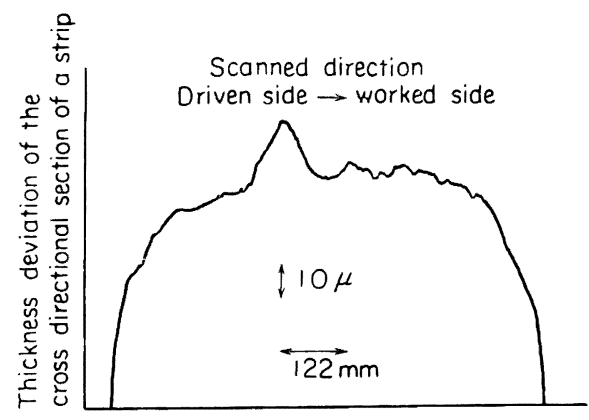

Cross directional position of a strip

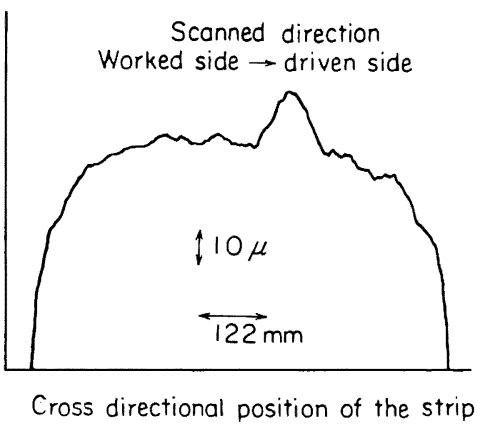

Cross directional position of the strip

Fig. I(2). The repeatability of the test instrument. 
を有していることがわかる.なおビルドアップも明確に 測定されることが判明した.

\section{$3 \cdot 1 \cdot 2$ マイクロメーター測定結果との比較}

r線鋼板クラウン計の精度はきわめてすぐれているこ とは前述のとおりであるが，この計測器による測定法は 絶対測定法ではないので，その測定値の信頼性を他の測 定方法との比較により確める必要がある. それゆえ従来 の最も標準的なマイクロメーターによる測定值と比較し た結果の1 例を Fig. 2 に示しておく. 図からみられる ようにこの両者の測定值の差はたかだか $5 \mu$ である. 、 イクロメーターの䛊差も約 $3 \mu$ はあり，これを考虑に入 れるときわめて信頼度の高い測定值を示していることが わかる.

\section{$3 \cdot 1 \cdot 3$ 測定記録と鋼板位置対応のつけ方の検討}

すでにFig. 1，Fig. 2 に示したように本装置によつて 鋼板の厚さを測定した場合鋼板の断面形状を描くが，こ の図形上の各点と鋼板の位置との対応をつけるのが重要 な問題である.とくに現行の管理基準のエッジから20〜 $30 \mathrm{~mm}$ 位置での厚さと, 中央での厚さとの比較により クラウン量を表示する方式では, エッジから $20 \mathrm{~mm} \mathrm{の}$ 位置の厚さを明確に検出することが重要になつてくる. しかるに放射線ビームは細い線ではなくある程度ひろが りを持つたものであるので，エッジの点で正確に立ちあ がらずにビームが完全に鋼板中に入つたところで立上が る. すなわちその間の遅れがあらわれる. その上，ビー ムが鋼板をはずれ直接検出箱に到達するときわめて大き な出力となるが, このような大出力の場合には, 増幅器 の動作範囲を逸脱してしまい，特殊な回路としない限り 回復に $1 \sim 2 \mathrm{sec}$ かかる. その間約 $30 \mathrm{~mm}$ 程度検出 部が進行してしまい立上りの遅れをいつそう大きくす る.

一方，線源部のスリットを細長い長方形にしてあるの

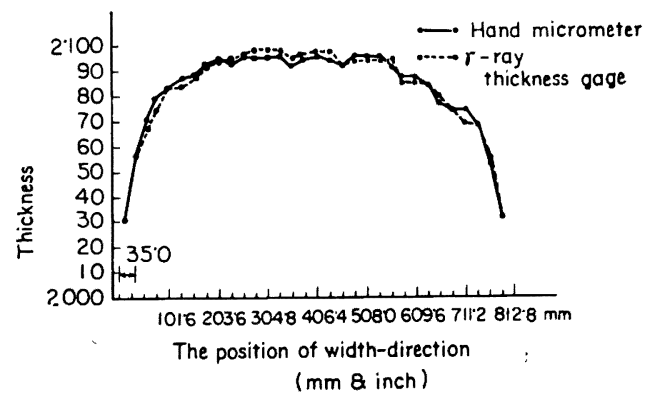

Fig. 2. Ciomparison between measured results of hot-rolled-sheet crown by a hand $\mathrm{mi}-$ crometer and the $\gamma$-ray thickness gage.

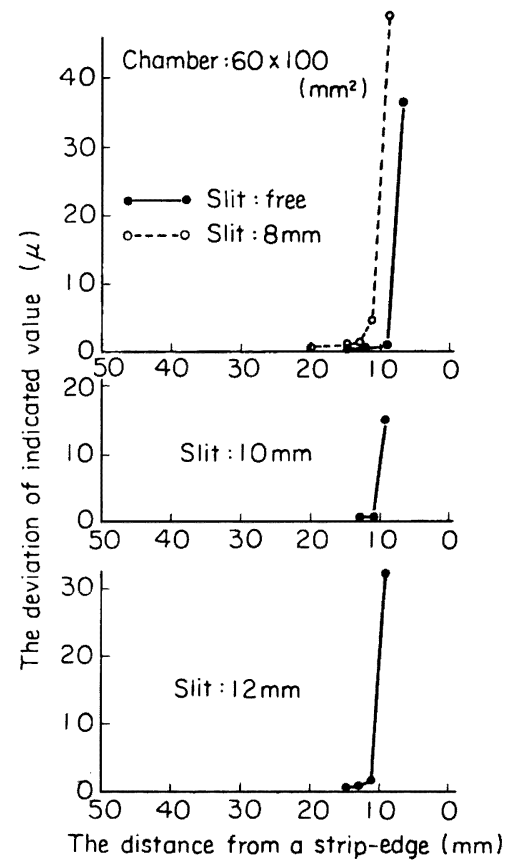

Fig. 3. Measurable areas near the edge.

で，かなりエッジ近傍まで，ビームが鋼板をはずれずに 測定できるはずである，そこで実験の順序としてまず検 出部静止の状態で，エッジ近傍何 $\mathrm{mm}$ まで測れるか実験 した.

エッジサイドにサンプルと同程度の厚さの板を置き， これをはずしたときに急激な出力差があらわれる位置を みつけ出し，その点をエッジ検出限界とした. このよう にして，測定した結果を Fig. 3 に示す.

スリット幅 $12 \mathrm{~mm}$ では, エッジより $15 \mathrm{~mm}$ まで, スリット幅 $10 \mathrm{~mm}$ ではエッジより $11 \mathrm{~mm}$ まで，スリッ 卜幅 $8 \mathrm{~mm}$ ではエッジより $9 \mathrm{~mm}$ まで測定可能である. 以上の測定は検出部を静止した場合のエッジ検出限界で あるが，検出部をライン外から移動させて測定する場合 には, 時定数分だけの指示遅れと, 前述の増幅器の飽和 現象からの指示遅れとで，エッジ検出がむずかしくな る.

とくに増幅器の脃和現象は指示遅れがはなはだしく， 本試験ではストリップェッジサイドに同程度厚さの添え 板をおいたりして種々検討したが，適切な解決方法は見 い出せなかつた. しかし電気回路的にはこの現象をとり 除くのは比較的容易なことである. それに反して回路時 定数の時間遅れは本質的な問題であり，これを皆無にす ることは不可能であり, 影響を無視できる程度に小さく 
しようとすると，放射線の統計摇動が大きくなり，実用 手段としては探用できない.

やむをえず鋼板のエッジ近傍でいつたん検出部を停止 してその位置での厚さを測定してから，幅方向に検出部 を走査せしめ，反対側のエッジ近傍で再び検出部を停止 せしめる方法を採用することにした．エッシシ検出は光電 式の方法で行ない，制動は電動機に逆トルクを与える方 法によつた，制動距蜼は実験的に求め決定した。

この処置により，エッジ近傍 $15 \mathrm{~mm}$ までは十分測定 可能であつた. この測定結果の記録には，X-Y レコー ダーが適当と考えられる.

通常の記録計では被測定鋼板幅の正確な幅からと記録 計の中心位置とから決定していかねばならない，エッジ 付近に，箔片か針金を置くことによりこの部分の瞬間 的な厚さ変化記録によりエッジ位置指示を試みたが，エ ッジから $30 \mathrm{~mm}$ 以内まではその指示があらわれなかつ た.

これに対し鋼板の中央部の位置対応はエッジに比較し 容易に対応がつけられる.

\section{$3 \cdot 1.4$ ビルドアップ測定}

模型実験として，50 上にのせて測定した結果を Fig. 4 に示す.

このように鋭い形状のビルドアップに対しては, 形状 がくずれてくるがビームがある程度ひろがりをもつてい るのでやむを得ない.

異常微小溜起すなわちビルドアップを，Fig. 5 に示し たような幅と高さのとり方で $\gamma$ 線ークラウン 計測定デー タとマイクロメーター測定データと比較してそれぞれ幅 $W$, 高さ $h$ を測定し，等価打点図に示した，それがFig. 6である. ビルドアップ高さについてはこの測定器の精

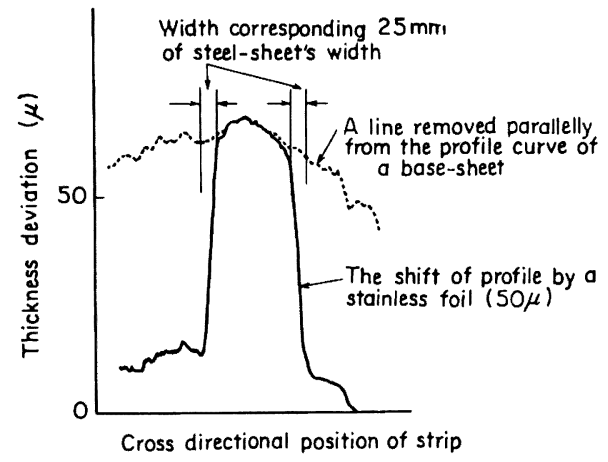

Fig. 4. Test example for unusual crown detection.

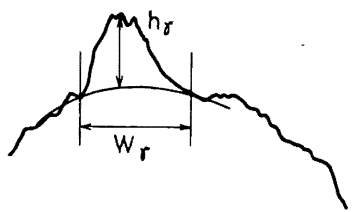

(1)

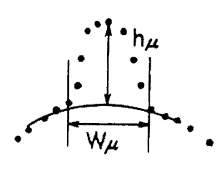

(2)
Fig. 5. Measurements of unusual crown by the $\gamma$-ray crown meter (1) and micrometer (2).

度からみて非常によく一致している．また，幅について も一応満足できる結果といえよう.

ビルドアップの測定された試料について，圧延方向人 $33 \mathrm{~mm}$ 間隔に 5 箇所のクラウンを測定した結果を Fig. 7 に示す. $r$ 線クラウン計とマイクロメーターとは非常 によく一致した形状および対応を示している。また，ビ ルドアップが長さ方向にある周期で存在している 1 例と 考えられる.

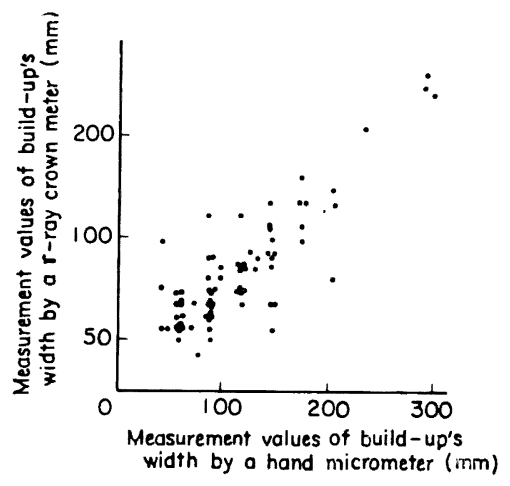

Fig. 6. Correlation figures of unusual crown height and width between the measured values by $\gamma$-ray crown meter and micrometer. 


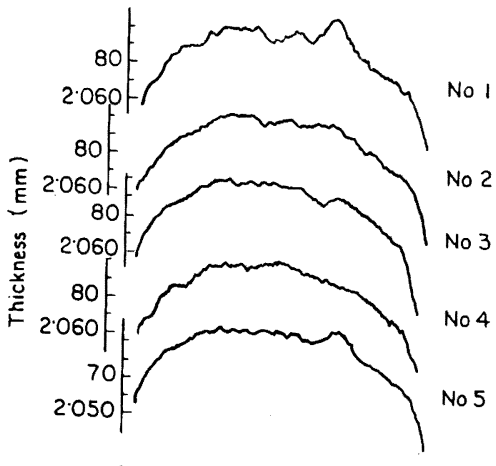

Cross directional position of a strip

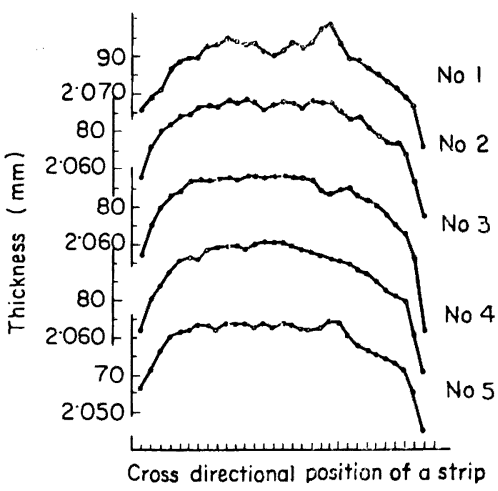

Cross directional position of a strip

Fig. 7. Profiles measured by $\gamma$-ray and hand micrometer at regular iniervals of $33 \mathrm{~mm}$ to longitudinal direction.

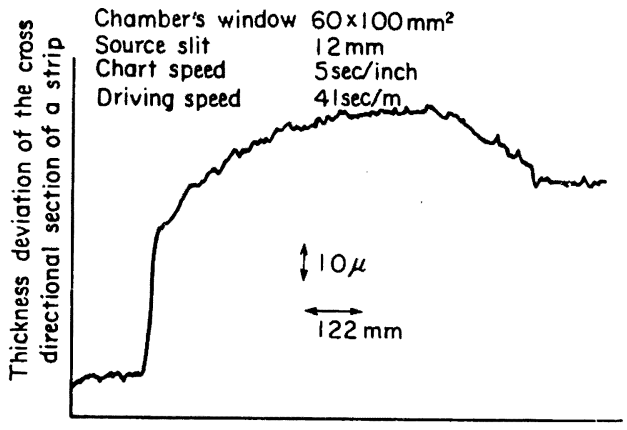

Cross directional position of a strip

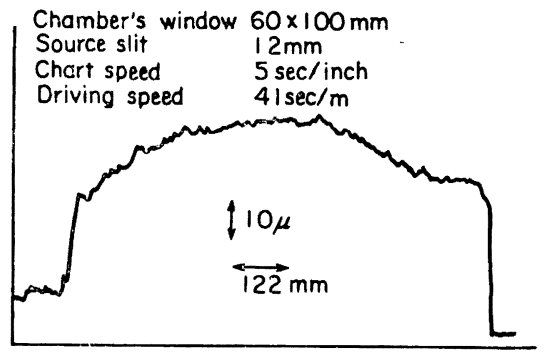

Cross directiona position of a strip

Fig. 8. Examples of measured profiles by on-line $\gamma$-ray crown meter. (pickling line)

\section{$3 \cdot 2$ ライン設置試験結果}

以上の実験公での子備試験ののちに装置を冷延工場酸 洗ラインに設置し，実際のラインでの測定を行なつた.

Fig. 8 にホットコイルのクラウン形状を測定した結 果の例を示す. Fig. 8(1) にはラインを停止した上で エッジから $20 \mathrm{~mm}$ の両端位置で静止測定し，その両点 の間を走査測定している。この 1 例はウェッジタイプの 鋼板であり，ドライブサイドの厚さが厚くなつている.

Fig. 8(2)はもう1例で，やはりラインを停止してか ら, エッジから $25 \mathrm{~mm}$ の位置で静止測定したものである. エッジ近傍管理位置の測定もこのように静止測定すれば 統計摇動が除かれた精度のよい測定值を得ることができ る.中央位置はビルドアップがなければほぼフラットな ので, 統計摇動があまり入つていない測定值を読みとる ことができる.

\section{4. 本装置について}

冷延工場酸洗ライン設置の鋼板クラウン形の仕様は基 本的には前述の試駼装置と同様のものであるが，これま での実駼結果をもとに若干の改良が加えられたものであ る. その特徵の主たるものをかいつまんで述べると，第 1 に ${ }^{241} \mathrm{Am}$ 線源を $5 \mathrm{~mm} \times 100 \mathrm{~mm}$ の長方形のものとし， $2 \mathrm{C}_{\mathrm{i}}$ のものを使用し, スリットは短棚状のものを使用し た.

エッジ管理位置の測定は正確を要するのと，この装置 がストリップの断面の厚さ偏差を精度よく指示する機能 をもつものであるため, 板厚レベルによる較正が必要で あるので，ラインを停止した上でェッジ検出装置で検出 部を静止させ測定した．計録計は X-Y レコーダーを使 用しクラウン形状の直観的把握を可能にした. 検出部の 駆動は $2 \mathrm{~m} / \mathrm{min} \sim 6 \mathrm{~m} / \mathrm{min}$ 亡で 3 段切換えとし，測定 
表 3 各種放射線源厚さ計の特徵

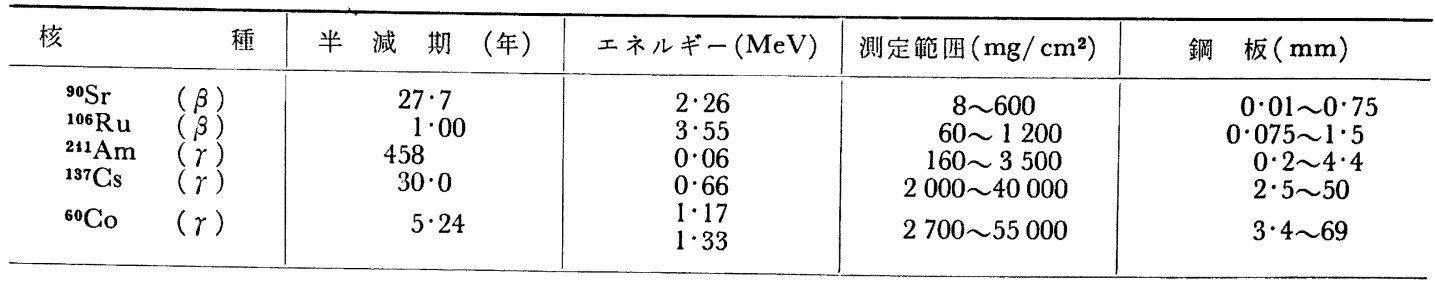

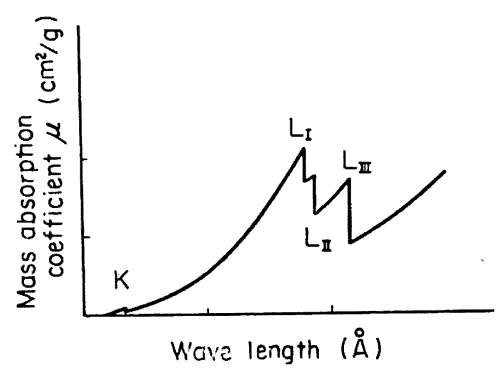

Fig. 10. Mass absorption coefficient curve of platinum6).

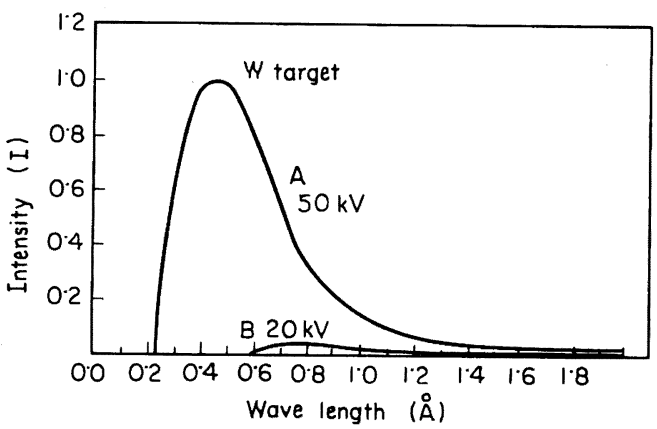

Fig. 11. White spectrum intensity produced by tungsten-target X-ray tube ${ }^{7}$.

されていた.これらのおのおのの厚さ計の特徵を表 3 に 示して扔く.

表 3 から見られるように $\beta$ 線は測定範囲が $1 \mathrm{~mm}$ 厚以 下の鋼板に限られていて, 利用範囲がきわめて狭い，ま た鋼板上の油膜とか水滴に，きわめて大きく影響を受け やすい．X線はX線管球のターゲットからの特性 X線と 電子粒から発生する制動放射線之から構成されていて後 者は連続スペクトルである.この連続スペクトルの発生 ということがX線厚さ計の精度に限界がある大きな原因 となつている.

すなわちX線エネルーギにより，それぞれの元素に応 じた吸収特性があり，その吸収特性が不連続的に変化す る. この様子を Fig. 10 に示しておく6). 引用例は白金 についてであるが他の元素についても同じ傾向の吸収曲
線となる．そのために発生放射線が連続スペクトルであ り，その強度分布が一定でない場合には含有元素の影響 が強くあらわれる．通常のX線管球によつて発生したX 線の強度分布はたとえば Fig. 11 のようになる7)。した がつて合金の場合，その合金元素含有量によつて絶えず 調整を必要とし, 数 $\mu$ の精度を要求される厚さ計の場合 には大きく問題になる. その上X線厚さ計は電源の変動 などが線源量の変動として直接あらわれてきてやはり誤 差の原因となる.

以上のような理由で $\gamma$ 線エネルギーはX $\mathrm{X}$ 線と同程度で しかもモノクロマティックなスペクトルを有する $\gamma$ 線源 が利用されれば上述の問題は解決されると予想されてい た. そこへ ${ }^{241} \mathrm{Am}$ の同位元素が比較的低価格でかつ容 易に入手できるようになつてきた．この も 458 年と非常に長く, きわめて好都合である.

事実この線源を利用した $\gamma$ 線厚さ計は前述のように非 常に高精度のものであり, プロフィルメーターへの応用 が可能になつたものである.

${ }^{241} \mathrm{Am} \gamma$ 線厚さ計のもう一つ大きな利点は，放射線遮 蔽がきわめて容易であるということである。 ${ }^{241} \mathrm{Am}$ は $\alpha$ 線と $\gamma$ 線を出すが， $\alpha$ 線の方は空気中で数 $\mathrm{cm}$ の飛程し か持たないのであるから問題ないし， $\gamma$ 線む鋼板 $5 \mathrm{~mm}$ 程度で全く安全なところまで遮蔽できる．したがつて作 業上の取扱いも，ビームに直接手を入れることさえなけ れば安全である. 形態もセラミック状に固着したもので あり, 密封線源として理想的な状態であるので，放射線 障害防止のための完壁な管理がきわめて容易にできる.

\section{3 鋼板クラゥン自動制御について}

基本的には A.G.C. (Automatic Gage Control) System と同様な原理で鋼板クラウンコントロールシステムが考 えられている. その具体的なものとしては 4 重圧延機に 応用した例として $T . A$. Fox の特許》にみられるよう なものである.

その他にもワークロールベンディング法，バックアッ プロールベンディング法9)が考察されている.

上の 3 方法で Fox タイプはワークロールチョックと バックアップロールチョックの間にハイドローリックシ 


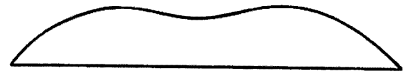

Fig. 12. Work roll bending crown shape9).

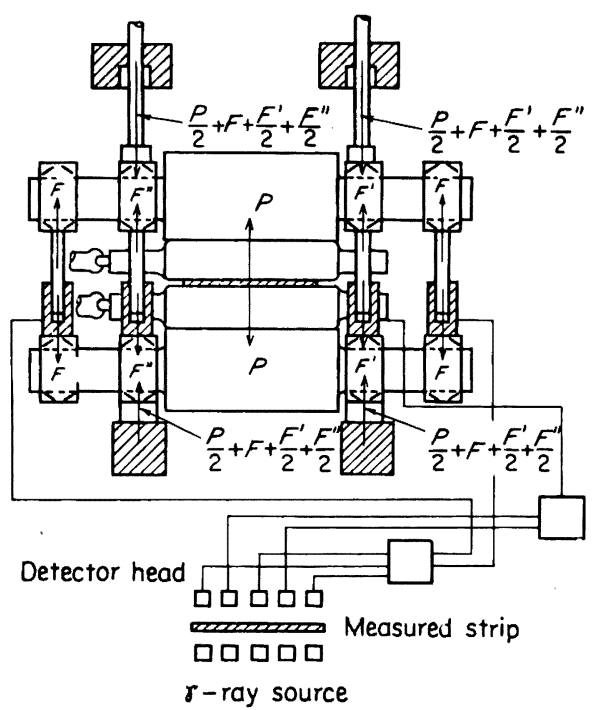

Fig. 13. Crown control system using back-up roll bending.

リンダーを入れ制御するものであり，ワークロールベ ンディング法はワークロールチョックの間にハイドロー リックシリンダーを入れるものである. そしてこれらの 2 万法はいずれも制御された鋼板の断面形状が Fig. 12 のようになると考えられている. これに対し，バックア ップロールベンディング法は理想的なクラウン制御が得 られるといわれている。

いずれにしても上に述べた各方法が理想的な機能を発 揮するためには，高精度の厚さ検出器が要求されてい た. そしてこれまでその条件が満たされていなかつたの である.

そこへこの ${ }^{241} \mathrm{Am}-\gamma$ 線厚さ計が開発されこの種厚さ 計の精度がいちじるしく高められたのでクラウンの自動 制御用として十分使用できるものとなつた．実際のクラ ウン制御は Fig. 13 に示すように 5 点の測定器を置き, 両端と中央のものでクラウンを制御し, 両側の測定器で ウェッジ制御をするのが望ましい方法である.このウェ ッシ制御方法を加えたバックアップロール彎曲法は U. E. の方法" ${ }^{9}$ に改良を加えた方法である. 図中 $\frac{P}{2}+F+$ $\frac{F^{\prime}}{2}+\frac{F^{\prime \prime}}{2}$ は A. G. Cシステムから指示される量であ り，厚さを設定するものである，Fは中央の測定器によ
る測定值と最も外側にある両測定器による測定值の平均 との差から指示される量である. $F^{\prime}$ は固定された量と しておいて $F^{\prime \prime} 2$ 番目と 4 番目の測定器による測定值 の差から指示される量とすればよい.

もちろん技術的に困難な点はまだ数多くある・たとえ ば厚さ計を複数個並们で使用するのであるから，その各 計器間の䛊差が当然加わつてくる. これを極力小さくす るために較正方法の確立が必要である. と同時に計器ド リフト，糜囲温度などの外部条件変動による指示值の変 動なら゙も極力小さくしなければならないままたたとえば 熱間压延機にこの自動制御機䛶をとりつける場合には， 高温下で適応できるようにすることも必要である.

最近のワークロールベンディング法の研究, 厚板での バックアップロールベンディング法の研究 ${ }^{10)}$ 成果からみ られるように近い将来, クラウンコントロールが現実の ものとしてクローズアップされる日も近い.

そのときにはこのクラウン自動制御技術の確立が強く 要望されるものと思われる.

\section{4 動的誤差の補正について}

この種の測定へッドを走査させる $\gamma$ 線測定器の誤差は 放射線源壊変にともなういわゆる統計摇動による䛊差, 電気回路による誤差と, 測定へッドの検出出力をメータ 一または記録計までに指示されるのにかなり長い時定数 をとり，結果として時間遅れによる指示誤差，いわゆる 動的誤差から棈成されている. 統計摇動による誤差は線 源量を増加させることにより $1 \mu$ 程度までは任意に小さ くできる，電気回路による誤差は現状で必要な程度には 十分小さくできる.

しかし最後の動的誤差は現在のところ解决していな い.この誤差があらわれる様子を Fig. 14 に示してお く. この動的誤差は全誤差のうちかなり大きな部分を占 めているので，これを改良できる見通しを得ておくこと

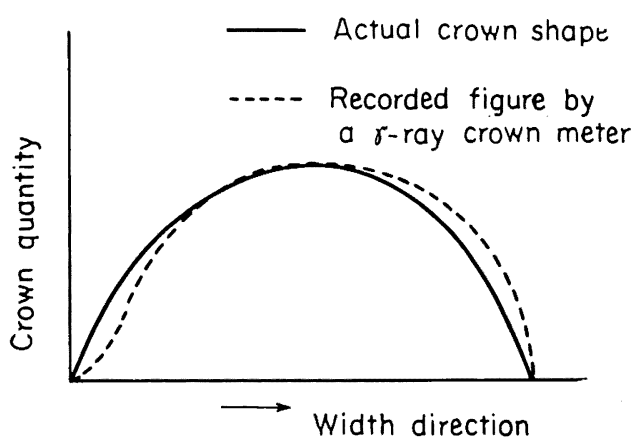

Fig. 14. Difference between recorded curve ${ }_{-i}^{-}$by $\gamma-$ ray crown meter and actual crown. 
は重要なことであり，ここに考察を加えておく.

この動的誤差が生ずる原因は，X・Y・レコーダーに記 録された場合， $\mathrm{X}$ 一方向入力は時間遅れがなく, $\mathrm{Y}$ 方向入 力に対しては時間遅れがあるために起こるものである.

そこでX方向入力も同じ時定数で遅らせた場合どうな るか，この動的誤差が補正できて正しい形状の記録が得 られるのではないかということが考えられる.

(1)

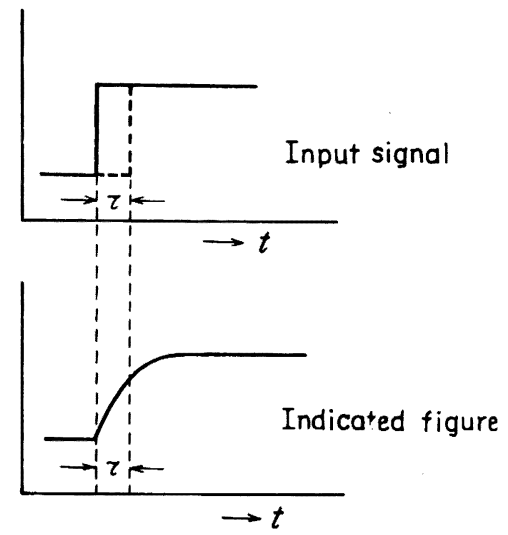

Fig. 15. Correspondence between input and output signals of the instrument having time constant $\tau$.

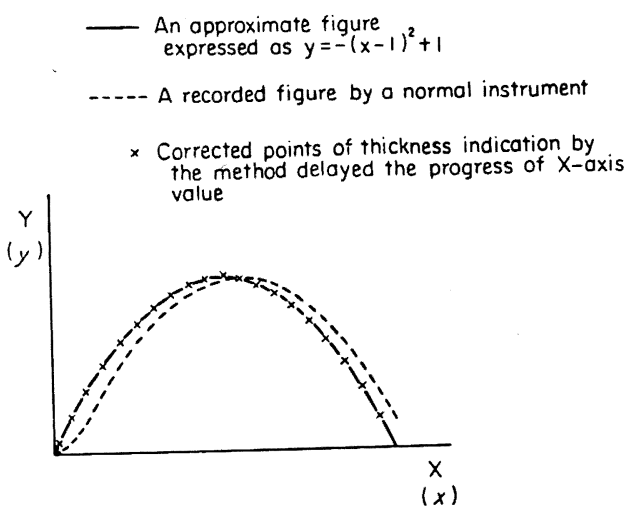

Fig. 16. Correction of recorded curve.

Fig. 15 にその実際の時間遅れの様子を示しておく.

Fig. 15(1) のような入力変化に対しての実際の応答が Fig. 15(2) のようになる. もしこれが(1)の破線で示 したような時間遅れを示すのであれば問題は簡単であ り，X軸に対してYと同じ時定数分の遅れをとらせるだ けで解決する.しかし実際には（2）のように変化するた めにこの方法で解决できるか否か検討をする必要があり これを計算で行なつた．その計算は後に示し，ここでは 結果だけを示しておく.
鋼板のクラウンの形状を

$$
y=-(x-1)^{2}+1
$$

と記述する. その形状は Fig. 16 に示すとおりである.

計算にあたつては $x=k t て ゙ ~ k=1$ とし $\tau=0.1 \mathrm{sec}$ とし て計算している. したがつて実在形状と記録形状のずれ は実際より誇張されて示されている.

$\mathrm{X} \cdot \mathrm{Y}$ レコーダーのX軸方向を通常の方法で走査させ ると，X-Y レコーダー上に描かれる曲線は Fig. 16 の 破線で示した曲線を記録する。

そこでX方向に時定数ての遅れ回路を入れると あらわした值を示す. すなわちきわめて正確な形状を $\mathrm{X}$ -Y レコーダー上に示してくれることがわかる. このよ うにしてクラウン形状記録装置の動的誤差を補正するこ とが可能となる. 実際の回路上の改良はR-G回路をX入力端前に入れ $\mathrm{RC}=\tau$

となるように R.C を定めてやればよい.

\section{6. 結 言}

${ }^{241} \mathrm{Am} \gamma$ 線厚さ計を改良した鋼クラウン形は十分な精 度で使用できる. その裏づけ実験として熱延コイルにつ いて測定した結果を列挙する.

（1）繰り返し精度は往復測定法で試験した結果往復 の差 $2 \mu$ 以下でおさまつている.

（2）マイクロメーターとの比較結果ではその差 $5 \mu$ 以下でおさまつている.

(3) ビルトアップについてもマイクロメーターで検 出したものと幅, 高さ共によい一致を示している.

（4）エッジ近傍の測定は測定へッドを一たん停止し て測定する方法をとれば $15 \mathrm{~mm}$ まではかれる.

(5) 測定は約 $1 \mathrm{~min}$ で完了する. 先行きの展望として次のことがいえる.

（1）測定精度は, 動的誤差の補正, 使用線源量の増 大などにより，さらに向上できる.

（2）クラウン自動制御のための検出器として開発し うる可能性を十分に持つている.

\section{Appendix}

時定数 $\tau$ の R-C 回路で $t=0$ で入力が $y=a$ に変化 したとき，メ一タ指示は $y=a\left(1-e^{-t / \tau}\right)$ と変化する. ここでクラウン形状を $y=f(x)$ とおく. 考察の段階で はノルマライズしておく. 同様に記録計での記録もノル マライズして $Y=F(X)$ とおいたとき， $F(x)=f(x)$ であればこの記録は鋼板断面形状を正確に記録している ことになる.

まず最初に X軸に時間遅れをとらない場合について考 察する. この場合 $x$ は時間と直線関係にあり 


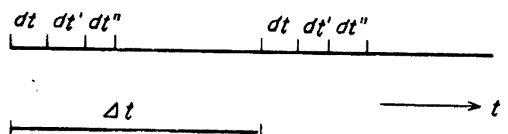

Fig. 17. Differencial time $d t, d t^{\prime}, d t^{\prime \prime}$, and $\Delta t$.

$x=k t$

とあらわされる、またこの条件のもとでは

$$
X=k t
$$

である.

一方 $Y(t)$ について考えてみると, スタート直後 $d t$ $\sec$ 後には

$$
Y(d t)=(y(\Delta t)-Y(0))\left(1-e^{-d t / \tau}\right)
$$

と書きあらわせる. $\Delta t$ についての考え方はやはり無限 小量ではあるが，Fig. 17 に示すとおりである. 次の $d t^{\prime}$ 後には

$$
\begin{aligned}
Y\left(d t+d t^{\prime}\right) & =(y(\Delta t+d t)-Y(d t))\left(1-e^{-d t^{\prime} / \tau}\right)+Y(d t) \\
& =(y(\Delta t+d t)-Y(d t))\left(1-e^{-d t / \tau}\right) \\
& +(y(\Delta t)-Y(0))\left(1-e^{-d t / \tau}\right)
\end{aligned}
$$

同様に次の $d t^{\prime \prime}$ 後には

$$
\begin{aligned}
Y\left(d t+d t^{\prime}+d t^{\prime \prime}\right) & =\left(y\left(\Delta t+d t+d t^{\prime}\right)-Y\left(d t+d t^{\prime}\right)\right) \\
& \left(1-e^{-d t^{\prime \prime} / \tau}\right)+Y\left(d t+d t^{\prime}\right) \\
& =\left(y\left(\Delta t+d t+d t^{\prime}\right)-Y\left(d t+d t^{\prime}\right)\right) \\
& \left(1-e^{d t^{\prime \prime} / \tau}\right)+(y(\Delta t+d t)-Y(d t) \\
& \left(1-e^{-d t^{\prime} / \tau}\right) \\
& +(y(\Delta t)-Y(0))\left(1-e^{-d t / \tau}\right)
\end{aligned}
$$

いま $d t, d t^{\prime}, d t^{\prime \prime} \ldots . .$. を等間隔にとつていくことはいつ こうに差しつかえないのだから

$$
\begin{aligned}
Y(t) & =\frac{1}{d t}\left\{\int_{0}^{t} y(t) d t-\int_{0}^{t} Y(t) d t\left(1-e^{-d t / \tau}\right)\right. \\
& =\frac{1}{\tau}\left(\int_{0}^{t} y(t) d t-\int_{0}^{t} Y(t) d t\right)
\end{aligned}
$$

ここで $\frac{d Y}{d X}$ を計算すると

$$
\frac{d Y}{d X}=\frac{d Y / d t}{d X / d t}=\frac{(y(t)-Y(t)) / \tau}{k}=\frac{y(t)-Y(t)}{k t}
$$

となる。

$$
\frac{d Y(t)}{d t}=\frac{1}{\tau} y(t)-\frac{1}{\tau} Y(t)
$$

から $Y(t)$ を求めると

$$
\begin{aligned}
Y(t) & =e^{-t / \tau} \int \frac{1}{\tau} y(t) e^{t / \tau} d t+c, e^{-t / \tau} \\
& =y(t)-\tau y^{\prime}(t)+\tau^{2} y^{\prime \prime}(t)-\tau^{3} y^{\prime \prime \prime}(t) \\
& +\tau^{4} y^{\prime \prime \prime \prime}(t) \cdots \cdots+c, e^{-t / \tau}
\end{aligned}
$$

となり $y(t)$ が $x$ の整函数形として表わせればこの $Y(t)$ はすこぶる単純な形で表現できる.

一方 X軸に同様に時間 $て$ の遅れ回路を入れると，前述

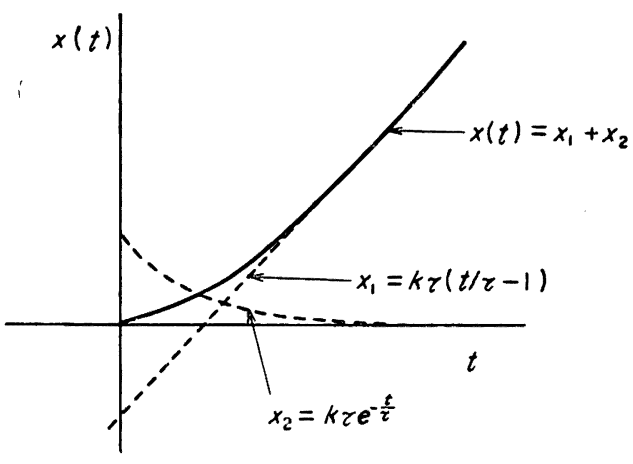

Fig. 18. Progress curve of $\mathrm{X}$-axis pen in case of insertion of $\tau$ delay circuit in $\mathrm{X}$-axis potentiometer.

の $Y(t)$ と同様に考えて全く同じ計算が行なわれる.す なわち

$$
X(t)=\frac{1}{\tau}\left(\int_{0}^{t} x(t) d t-\int_{0}^{t} X(t) d t\right)
$$

両辺を微分すると一階の線型微分方程式になる

$$
\begin{aligned}
& \tau \frac{d X(t)}{d t}=x(t)-X(t) \\
& x(t)=k t \text { であることから }
\end{aligned}
$$

これを解けば

$$
X(t)=k \tau\left(\frac{t}{\tau}-1\right)+k \tau e^{-t / \tau}
$$

となる.ここで積分定数を求めるために初期条件を入れ た.この式を図示すれば Fig. 18 のようになる.

$$
\begin{aligned}
& \text { また } \frac{d Y}{d X} \text { は } \\
& \frac{d Y}{d X}=\frac{d Y / d t}{d X / d t}=\frac{(y(t)-Y(t)) / \tau}{(x(t)-X(t)) / \tau}=\frac{\Delta y}{\Delta x} \cong \frac{d y}{d x}
\end{aligned}
$$

すなわち，記録形状と，実際の形状とがよく一致してい ることを示している.

現実にクラウン形状が

$$
y=-(x-1)^{2}+1
$$

で近似できる場合実在のクラウン形状と，従来の $\mathrm{X}-\mathrm{Y}$ 記録と，改良後の $\mathrm{X}-\mathrm{Y}$ 記録とを図示したのが前揭の Fig. 16 である.

\section{文献}

1 ) 三輸, 水越, 西村: 原子力工業, 12 (1966) 10, p. 67

2) 第 5 回理工学における同位元素研究発表会 1968, 4 月, p. 16

3 ) Iron Steel Eng., (1968), August, p. 147

4 ) 城戸, 西脇, 条川, 島崎, 乾, 川瀬: 東芝レビュ 一, 23 (1968) 10, p. 16

5 ) 第 50 回計測部会資料 (日立製作所), 1972年 3 月 
6) A. GUINIER：X線結晶学の理論と実際 (高良他訳)，p. 14 (理学電機図書出版社)

7 ) H. A. LiebHAFSKY, et al.: “分析化学者のためX 線分光分析法” (柴田他訳), p. 6 (理学電機図書 出版社)
8 ）特許出願公告, 昭40-19734（1965 年 9 月）

9 ) $M . D$. Stone and R. Gray: Iron Steel Eng., 42 (1965) 8, p. 73

10) $K$. Kono and $H$. Nakamura: Proceedings ICSTIS, Suppl. Trans. ISIJ, 11 (1971), p. 684 